\title{
Toxicology of Marine Mammals: New Developments and Opportunities
}

\author{
Liesbeth Weijs $^{1} \cdot$ Annalisa Zaccaroni $^{2}$
}

Received: 23 March 2015/Accepted: 25 September 2015/Published online: 26 October 2015

(C) Springer Science+Business Media New York 2015

\begin{abstract}
It is widely recognized that marine mammals are exposed to a wide variety of pollutants, with a weight of evidence indicating impacts on their health. Since hundreds of new chemicals enter the global market every year, the methods, approaches and technologies used to characterize pollution levels or impacts are also in a constant state of flux. However, legal and ethical constraints often limit the type and extent of toxicological research being carried out in marine mammals. Nevertheless, new and emerging in vivo, in vitro as well as in silico research opportunities abound in the field of marine mammal toxicology. In the application of findings to population-, species-, or habitatrelated risk assessments, the identification of causal relationships which inform source apportionment is important. This, in turn, is informed by a comprehensive understanding of contaminant classes, profiles and fate over space and time. Such considerations figure prominently in the design and interpretation of marine mammal (eco)toxicology research. This mini-review attempts to follow the evolution behind marine mammal toxicology until now, highlight some of the research that has been done and suggest opportunities for future research. This Special Issue will showcase new developments in marine mammal
\end{abstract}

Liesbeth Weijs

1.weijs@uq.edu.au

Annalisa Zaccaroni

annalisa.zaccaroni@unibo.it

$1 \quad$ National Research Centre for Environmental Toxicology (ENTOX), The University of Queensland, 39 Kessels Road, Coopers Plains, QLD 4108, Australia

2 Department of Veterinary Medical Sciences, University of Bologna, Viale Vespucci 2, 47042 Cesenatico, FC, Italy toxicology, approaches for exposure-effect research in risk assessment as well as future opportunities.

Toxicology of marine mammals is a relatively small, but indispensable topic within the area of marine mammal sciences. It is a topic that has gained interest over the years due to the increased awareness of the toxic effects of pollutants in several organisms and the usually elevated levels of pollutants detected in marine mammal species (e.g. Tanabe et al. 1994; Ross 2000; Aguilar et al. 2002; Houde et al. 2005; Law et al. 2010). Despite being in contaminated habitats, marine mammals get the bulk of their body burdens through their diet rather than directly from their environment (Gray 2002). It is because of their top position in the trophic chain, the biomagnification process and the persistence of several pollutants, that marine mammals can accumulate high levels of pollutants. For biologists, marine mammal toxicology might be a highly theoretical and complex topic that sometimes seemingly abandons all connections with conservation and management. The ultimate goal in marine mammal toxicology, however, is to find minimally invasive and nondestructive tools or approaches that help to understand the causal link between pollution and its effects in marine mammals in order to (1) assess the past and current situation in terms of toxicology for marine mammals and to use that to (2) inform legislation for providing a healthier environment for these animals. This is a goal that will be valid for years and possibly decades to come and that fits seamlessly within any effort for conservation and management.

Since hundreds of new chemicals enter the global market every year, the methods, approaches and technologies used to characterize pollution levels or impacts 
are generally also in a constant state of flux. This is also true for the methods, approaches and techniques used in marine mammal toxicology, despite the legal and ethical constraints when working with these animals. New and emerging in vivo, in vitro as well as in silico research opportunities abound in the field of marine mammal toxicology, both in exposure studies as well as in effect studies. A comprehensive understanding of contaminant classes, profiles and fate over space and time can have a profound influence on the design and interpretation of marine mammal effect studies. This paper will provide a brief overview of past and current in vivo, in vitro and in silico research thereby stimulating future research opportunities in this topic (Fig. 1).

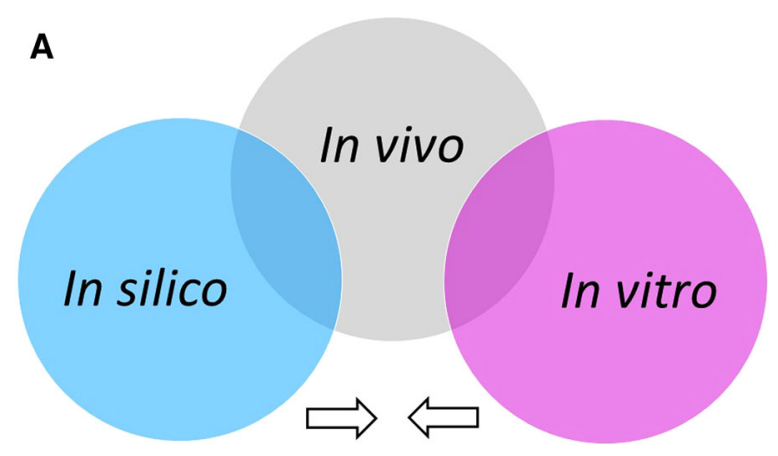

B

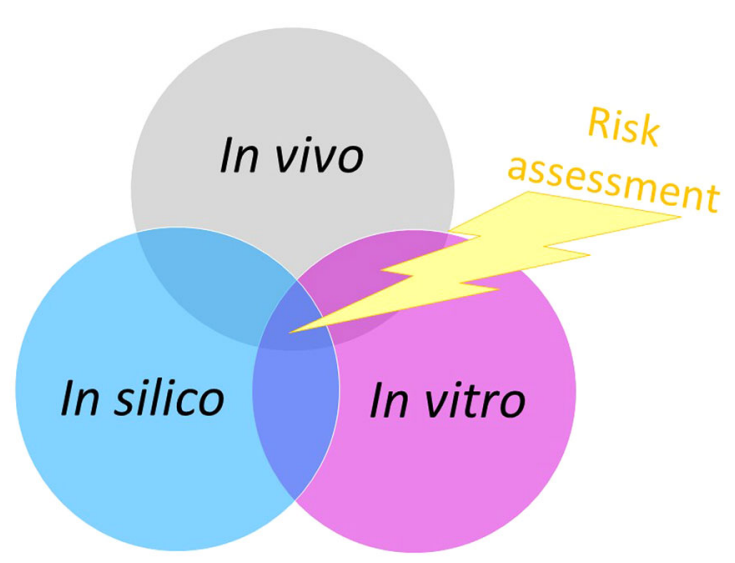

Fig. 1 Conceptual diagram of the different types of research that are underlying risk assessment in marine mammals. a represents the current situation in which results of in vitro research are difficult to implement in in silico models. b represents the ideal scenario in which all research types complement each other thereby facilitating (I) a thorough interpretation and understanding of current and past risks, as well as (II) an educated prediction and identification of risks in the future

\section{Overview of In Vivo, In Vitro and In Silico Research Directions in Marine Mammal Toxicology}

\section{In Vivo Research}

Following the protective guidelines and legislation for marine mammals, in vivo research is uncommon in marine mammals these days and is restricted mainly to collecting samples in a minimally invasive to non-invasive way. In the past, experiments using animals held in captivity were performed in a limited number of occasions (Tillander et al. 1972; Ramprashad and Ronald 1977; Van de Ven et al. 1979; Reijnders 1986; Ross et al. 1996a, b; De Swart et al. 1996; Thomas et al. 2005). These studies differ in a number of ways such as the administration type (e.g. fish from contaminated regions, spiked oils/fish), administered dose which was more realistic in the more recent studies (e.g. Reijnders 1986; Ross et al. 1996a, b) compared to the older ones (e.g. Tillander et al. 1972; Ramprashad and Ronald 1977) and general outcomes [fatalities were recorded in Ramprashad and Ronald (1977)]. Nevertheless, effects on the immune (Ross et al. 1996a, b; De Swart et al. 1996), sensory (Ramprashad and Ronald 1977) and reproductive systems (Reijnders 1986) were found thereby providing evidence that pollutants could be associated with adverse effects. To our knowledge, similar experiments were never performed using marine mammal species other than pinnipeds and were not performed for any marine mammal species in the last decade.

These days, in vivo research in marine mammals refers mainly to sampling techniques rather than to exposure experiments on animals in captivity. Blood and biopsy sampling can be done in a minimally to non-invasive manner both in animals in captivity as well as wild animals. Because blood and biopsy samples are often very fresh, they are ideal samples for studies involving health effect as well as chemical analysis. However, the majority of the biomonitoring studies, i.e. studies focussing on chemical analysis only, are still done using tissues of animals that were found dead on the beach or in fishing nets or that had died naturally. Those studies can investigate several types of pollutants in a wide array of tissues, but are sometimes also perceived as biased and untruthful with respect to the state of the population they are drawn from. Although dead or stranded animals are not necessarily ill, studies using tissues from traditionally harvested marine mammals can target specific animals regarding age class, gender or health status. Such studies, however, are obviously not classified as minimally to non-invasive (e.g. Tilbury et al. 2002; Brown et al. 2014). 
Nevertheless, in addition to capture-and-release studies, studies using harmless sampling methods in live marine mammals are definitely gaining momentum. Tissues that qualify for harmless sampling are hair, skin, biopsies, faeces, urine and blood. A thorough review about the use of these matrices to study the physiology, and toxicology to a smaller extent, of larger marine mammals is provided by Hunt et al. (2013). Faeces and urine are typically hard to obtain for marine mammals in general, especially for cetaceans that never come to the land. Goldstein et al. (2009) collected sea lion (Zalophus californianus) faeces for domoic acid analysis, and Roman and McCarthy (2010) investigated humpback whale (Megaptera novaeangliae) fecal plumes to test the whale pump hypothesis which refers to the recycling process of nitrogen in the marine environment. A similar approach was done by Lavery et al. (2010) for sperm whales (Physeter macrocephalus) that stimulate carbon export to the atmosphere by producing iron-rich faeces. Marine mammal faeces were also investigated by Marcus et al. (1998) for elucidating harbour and grey seal (Phoca vitulina and Halichoerus grypus) diets, for revealing the gut microbial diversity of polar bears (Ursus maritimus; Glad et al. 2010), and for investigating nutritional stress in killer whales (Orcinus orca; Ayres et al. 2012).

Needless to say that faeces or urine of marine mammals have not been the subject of many toxicological studies so far. Metals were analysed in hair samples of pinnipeds (e.g. Wenzel et al. 1993; Habran et al. 2013) as well as in hair of polar bears (e.g. Born et al. 1991; Jaspers et al. 2010). Among all tissues that can be obtained in a minimally to non-invasive manner from marine mammals, skin and blubber biopsies and blood are probably the most popular. Several health points (e.g. vitamin A, hormones) can be measured in these matrices. Also, a variety of pollutants have been measured in skin and blubber biopsies (e.g. Newman et al. 1994; Hall et al. 2003; Foltz et al. 2014) as well as in blood (e.g. Newman et al. 1994; Hall et al. 2003; Das et al. 2008; Weijs et al. 2009), but the most important reason for using these tissues is their usefulness in ex vivo/ in vitro experiments.

\section{In Vitro Research}

The development of in vitro techniques has allowed for the evaluation of toxicological effects without the use of live animals. An early in vitro study performed with marine mammal cells focused on the effect of heavy metals on steroid production in grey seals (Freeman and Sangalang 1977). That study outlined how selenium (Se) and arsenic (As) could induce, at relatively low concentrations $(0.45 \mu \mathrm{g} / \mathrm{g})$, an alteration in steroid hormone synthesis, thereby impairing the correct gonadic functionality.
Present studies focus mainly on the evaluation of enzymatic induction by different organic pollutants (e.g. Fossi et al. 2006, 2008; Marsili et al. 2008; Spinsanti et al. 2008) and on the evaluation of immunotoxicity and metabolic activity for pollutant breakdown or biotransformation (e.g. Boon et al. 1998; De Guise et al. 1998; Kim et al. 1998; White et al. 2000; Nakata et al. 2002; Levin et al. 2004, 2007; Mori et al. 2006; Wilson et al. 2007; Camara Pellissò et al. 2008). Several of these studies use blood samples collected from animals held in controlled environments that are trained for blood sampling. This minimizes the stress due to capture and constraint procedures that can alter immune responses. Levin et al. (2007) reported that captive and wild sea otters (Enhydra lutris) differ in their in vitro response to different organochlorine mixtures, with wild animals being more sensitive to contaminants compared to captive animals. The effect of capture stress and of exposure to pollutants in the wild are reported as possible explanations for observed differences.

Most studied species are those more commonly held in captivity, i.e. bottlenose dolphins (Tursiops truncatus), beluga whales (Delphinapterus leucas) and pinnipeds, while studied compounds are organohalogenated, i.e. PCBs (polychlorinated biphenyls), organochlorine and brominated compounds (De Guise et al. 1998; Levin et al. 2004, 2007; Mori et al. 2006). Nevertheless, there are also studies reporting immunotoxicity in relation to heavy metal exposure (e.g. Camara Pellissó et al. 2008; Dupont et al. 2013). Studies on wild individuals have been extensively performed in seals, which are somewhat easier to capture with respect to cetaceans, allowing sampling (blood, skin, etc.) for in vitro studies (e.g. Mori et al. 2006; Das et al. 2008; Frouin et al. 2008; Kakuschke et al. 2011; Dupont et al. 2013).

Most in vitro studies in marine mammal toxicology use cells derived from biopsies, blood samples or tissues originating from freshly dead animals, and these cells are then exposed to single contaminants or mixtures in order to evaluate the induced effects. Such cell systems are not perfect animal surrogates as they lack the multi-organ effect as well as important processes that ensure a realistic pollutant kinetics (Gauthier et al. 1999; Fossi et al. 2000). However, they allow to perform mechanistic and empirical studies, to investigate toxic effects at the cellular and molecular level, and to identify species-specific differences in toxic impacts which are impossible to study in vivo (Fossi et al. 2000). Apart from these studies, an additional step forward in in vitro studies has been the development of biosensor systems, which use engineered cells (i.e. bioassays) to be applied to marine mammals and concepts like 'effect-driven approach' (EDA), 'adverse outcome pathway' (AOP) and 'toxicity pathway' (Yordy et al. 2010; Burgess et al. 2013; Jin et al. 2013, 2015; Simon et al. 
2013). These developments allow to screen marine mammal tissue samples with respect to specific endpoints and, depending on the study design, can be used as an initial step to explore the influence of contaminant mixtures.

Several studies have underlined how mixtures can have a stronger effect on immune system than individual compounds (De Guise et al. 1998; Levin et al. 2004, 2007; Mori et al. 2006). In addition, Levin et al. (2004) have found that bottlenose dolphins are more sensitive to organochlorine mixtures than beluga whales thereby pointing towards a species-specific sensitivity. Various studies have also shown that organochlorine compounds can have an AhRindependent mechanism of action, thereby indicating that the sensitivity of marine mammals could not be predicted from results obtained from other species (Levin et al. 2004, 2007; Mori et al. 2006). As bioassays are based on specific cell lines derived from other species like rodents or humans, one can argue that the observed responses to contaminant mixtures are not necessarily the same as the responses experienced by marine mammals in the wild. Despite this, the toxicity pathways highlighted by bioassays are usually well conserved pathways across species. Together with the possibilities to screen marine mammal tissue samples and to point towards the need for detection of novel, emerging contaminants, bioassays can provide important topics and opportunities for future research.

Overall, in vitro studies have been performed mainly using hepatic cells (e.g. Boon et al. 1998; Kim et al. 1998; White et al. 2000), but in recent times, fibroblast and integument cells are used as substitutes for liver cells. These tissues can be obtained from skin biopsies which can be collected from wild animals with little damage to the animal (e.g. Fossi et al. 2000, 2006; Marsili et al. 2000; Wilson et al. 2007). Fibroblasts can be cultured and preserved in liquid nitrogen, thus reducing the need of continuous sampling from freshly dead animals, as requested with hepatic microsomal preparations. Integument cells also can be used for metabolic activity evaluation, as many studies have proven that cytochrome $\mathrm{P} 450$ is expressed in all cell types of integument, and that expression can be induced by various contaminants (Wilson et al. 2007). Therefore, fibroblast and integument cell cultures can be used to study differences in pollutant metabolism thereby providing rapid and simple alternatives for biomarker research in live animal investigations.

\section{In Silico Research}

Modelling allows to interpret and observe biomonitoring data from several different angles and provides a wholebody approach that in vivo nor in vitro research can offer. Models come in all sizes and shapes and are, in marine mammal toxicology, highly dependent on the availability of data (i.e. concentrations measured in tissues) and parameters (i.e. species-specific and compound-specific constants, rates and equations). In the pharmaceutical industry, models are compulsory and cost-effective tools; they are required to make sure that a specific drug is capable of reaching the target site and that the administered dose is sufficient for its purpose. The best way to know this is by gaining information about all the processes that are involved in the kinetics of the drug of interest, namely the absorption, distribution, metabolism and excretion pathways. Models in marine mammal toxicology follow the same principles, but face probably more challenges as the biology and physiology of most marine mammal species is often scarcely known and biomonitoring data is usually focussed on just a few tissues. Nevertheless, several types of marine mammal models are available for cetaceans and pinnipeds (reviewed in Weijs et al. 2014) and polar bears (Sonne et al. 2009; Pavlova et al. 2014).

The first bioaccumulation model for a marine mammal species was published in 1999 by Hickie et al. (1999). This model was developed for marine mammals and applied to the sum of PCBs in beluga whales. The Hickie et al. (1999) model is the only model based on the fugacity approach in which the thermodynamic equilibrium between phases is responsible for the distribution and partitioning of pollutants. A second model for the lifetime bioaccumulation of the sum of PCBs in beluga whales was published shortly after that, though this was not based on the fugacity approach but on the approach that involves concentration fluxes and chemical potential (Hickie et al. 2000). Other models that followed were for PCBs in harbour seals from San Francisco, Arctic ringed seals (Phoca hispida), bottlenose dolphins from Florida, killer whales (Orcinus orca) from the northeastern Pacific Ocean region, polar bears from Greenland, long-finned pilot whales (Globicephala melas) from Australia and harbour porpoises (Phocoena phocoena) from the Black and North Sea (reviewed in Weijs et al. 2014). Other POPs (persistent organic pollutants), such as pesticides and PBDEs (polybrominated diphenyl ethers) were modelled in polar bears, harbour porpoises, and killer whales (reviewed in Weijs et al. 2014). As can be seen in this list, models were only made for POPs so far and models for the lifetime bioaccumulation of metals have yet to be developed in any marine mammal species.

For some species it is more difficult to find suitable parameters than for others. In vitro experiments in marine mammal toxicology usually use single pollutants and known doses. This would be an ideal scenario for developing models. However, all models for marine mammals so far, were validated against real-life values obtained through biomonitoring studies. Diets of wild animals are often poorly characterized, conditions in the wild are by 
definition uncontrollable and wild animals are always exposed to pollutant mixtures which means that results of in vitro experiments cannot straightforwardly be used for modelling purposes (Fig. 1a). It is also because of these issues that several parameters had to be estimated in the existing marine mammal models leading to the addition of statistical methods for more reliable parameter estimation (Weijs et al. 2014).

\section{Conclusions and Research Needs}

Toxicological studies in marine mammals are hardly straightforward due to the protective guidelines that aim to protect marine mammals (inter)nationally. Although there is no doubt about the necessity and usefulness of these conservation guidelines, they put constraints on the toxicological work that can be done for marine mammals. This explains the knowledge gaps that still exist, the careful interpretation of research outcomes as well as the methods and techniques that are employed in marine mammal toxicology.

In this Special Issue, we have tried to showcase the current knowledge, novelties and opportunities in marine mammal toxicology. The field of marine mammal toxicology is broad and diverse, which is evidenced by the different topics, techniques, and species. Out of 14 studies in total, seven are biomonitoring studies, four studies combine chemical analysis and health effects (in vitro) and three are modelling studies (in silico). All three modelling studies have studied POPs: PBDEs in the killer whale food chain (Alava et al. 2015), PCBs and OCPs in the beluga whale (Cadieux et al. 2015) and PCBs in polar bears (Pavlova et al. 2015).

Brown and Ross (2015) have focussed on the transplacental transfer of PCBs, PBDEs and OCPs in ringed seal mother-fetus pairs. Noel et al. (2015) and McHuron et al. (2015) have investigated the influence of biological factors (e.g. age, gender, location) on the bioaccumulation of total mercury (THg) in hair/whiskers (Noel et al. 2015) and hair/ blood (McHuron et al. 2015) of harbour seals and California sea lions, respectively. Peterson et al. (2015) have studied the relationship between THg levels in blood and hair in four different pinniped species. Kakuschke and Griesel as well as Hansen et al. (2015) have analysed a battery of trace elements in marine mammals: in blood of harbour seals (Kakuschke and Griesel 2015) and in liver of 16 cetacean Species (Hansen et al. 2015). Furthermore, although it is often very difficult to obtain feces samples of cetaceans, Lundin et al. (2015) have managed to obtain and analyse feces samples of killer whales.

Results of these biomonitoring studies can be compared to toxicity thresholds or previously reported effect levels, however, they do not have the same direct correlations between exposure and effect as the effect-studies in this Special Issue. Reiner et al. (2015), Lehnert et al. (2015), Bogomolni et al. (2015) and Dupont et al. (2015) have investigated the correlations between different toxic endpoints and the levels of POPs (Reiner et al. 2015; Lehnert et al. 2015; Bogomolni et al. 2015) or trace elements (Lehnert et al. 2015; Dupont et al. 2015) in tissues of pinnipeds. These endpoints range from vitamin $\mathrm{A}$ and $\mathrm{E}$ measurements (Reiner et al. 2015) to cellular/molecular biomarkers and haematology (Lehnert et al. 2015; Bogomolni et al. 2015; Dupont et al. 2015). In addition to this, Bogomolni et al. (2015) have ventured a step further and have investigated whether exposure increased the likelihood to Phocine Distemper Virus.

The discipline of toxicology in marine mammals has come a long way, for in vivo, in vitro as well as in silico research, but we are not quite there yet. Knowing that the highest levels of pollutants were detected in killer whales and polar bears, that pollutants are causing immunotoxicity in several marine mammal species or that the elimination half-life of pollutants can be longer than the entire lifetime of a marine mammal, is obviously very useful. All those findings, and many more, have prompted toxicologists for decades to continue investigating marine mammals and to be increasingly creative in solving important questions.

However, for a streamlined approach to conserve and manage marine mammal populations, studies have to be combined and results need to complement each other as has been proposed earlier by Ross (2000). It is the interface between in vitro, in vivo and in silico research that is of great importance for future conservation and management purposes (Fig. 1b). Unfortunately, it is also that interface that is the most challenging, especially in an ever-changing environment. Exposure has changed over time and new compounds are becoming more and more important, even if 'old' pollutants still have an important role in marine mammal toxicology. Future research should take this into account and also focus on more novel and emerging compounds. Pollution differs spatially, meaning that more site-specific knowledge about dietary and ecological factors should be integrated in toxicological research to thoroughly understand the degree of exposure and impact on marine mammal populations. Finally, new biomarkers need to be developed and implemented in addition to the more 'traditional' ones parallel with the analysis of novel and emerging compounds in order to streamline conservation efforts for the next decades.

Acknowledgments Liesbeth Weijs and Annalisa Zaccaroni would like to thank Peter Ross for the opportunity to be guest editors for this Special Issue. We are also grateful to all authors who have contributed to this Special Issue. 


\section{References}

Aguilar A, Borrell A, Reijnders PJH (2002) Geographical and temporal variation in levels of organochlorine contaminants in marine mammals. Mar Environ Res 53:425-452

Alava JJ, Ross PS, Gobas FAPC (2015) Food web bioaccumulation model for resident killer whales from the Northeastern Pacific Ocean as a tool for the derivation of PBDE-sediment quality guidelines. Arch Environ Contam Toxicol. doi:10.1007/s00244015-0215-y

Ayres KL, Booth RK, Hempelmann JA, Koski KL, Emmons CK, Baird RW, Balcomb-Bartok K, Hanson MB, Ford MJ, Wasser SK (2012) Distinguishing the impacts of inadequate prey and vessel traffic on an endangered killer whale (Orcinus orca) population. PLoS One. doi:10.1371/journal.pone.0036842

Bogomolni A, Frasca S Jr, Levin M, Matassa K, Nielsen O, Waring G, De Guise S (2015) In vitro exposure of harbor seal immune cells to Aroclor 1260 alters phocine distemper virus replication. Arch Environ Contam Toxicol. doi:10.1007/s00244-015-0178-z

Boon JP, Sleiderink HM, Helle MS, Dekker M, van Schanke A, Roex E, Hillebrand MTJ, Klamer HJ, Govers B, Pastor D, Morse D, Wester PG, de Boer J (1998) The use of a microsomal in vitro assay to study phase I biotransformation of chlorobornanes $\left(\right.$ Toxaphene ${ }^{\circledR}$ ) in marine mammals and birds: possible consequences of biotransformation for bioaccumulation and genotoxicity. Comp Biochem Physiol C 121:385-403

Born EW, Renzoni A, Dietz R (1991) Total mercury in hair of polar bears (Ursus maritimus) from Greenland and Svalbard. Polar Res 9:113-120

Brown TM, Ross PS (2015) Transplacental transfer of polychlorinated biphenyls, polybrominated diphenylethers, and organochlorine pesticides in ringed seals (Pusa hispida). Arch Environ Contam Toxicol. doi:10.1007/s00244-015-0191-2

Brown TM, Ross PS, Reimer KJ, Veldhoen N, Dangerfield NJ, Fisk AT, Helbing CC (2014) PCB related effects thresholds as derived through gene transcript profiles in locally contaminated ringed seals (Pusa hispida). Environ Sci Technol 48: 12952-12961

Burgess RM, Ho KT, Brack W, Lamoree M (2013) Effects-directed analysis (EDA) and toxicity identification evaluation (TIE): Complementary but different approaches for diagnosing causes of environmental toxicity. Environ Toxicol Chem 32:1935-1945

Cadieux M, Muir D, Beland P, Hickie BE (2015) Lactational transfer of polychlorinated-biphenyls (PCBs) and other organochlorines in St. Lawrence beluga whales (Delphinapterus leucas). Arch Environ Contam Toxicol. doi:10.1007/s00244-015-0223-y

Camara Pellissó S, Munoz MJ, Carballo M, Sánchez-Vizcaíno JM (2008) Determination of the immunotoxic potential of heavy metals on the functional activity of bottlenose dolphin leukocytes in vitro. Vet Immunol Immunopathol 121:189-198

Das K, Siebert U, Gillet A, Dupont A, Di-Poi C, Fonfara S, Mazzucchelli G, De Pauw E, De Pauw-Gillet MC (2008) Mercury immune toxicity in harbour seals: links to in vitro toxicity. Environ Health 7:52. doi:10.1186/1476-069X-7-52

De Guise S, Martineau D, Beland P, Fournier M (1998) Effects of in vitro exposure of beluga whale leukocytes to selected organochlorines. J Toxicol Environ Health A 55:479-493

De Swart RL, Ross PS, Vos JG, Osterhaus ADME (1996) Impaired immunity in harbour seals (Phoca vitulina) exposed to bioaccumulated environmental contaminants: review of a long-term feeding study. Environ Health Perspect 104:823-828

Dupont A, De Pauw-Gillet MC, Schnitzler J, Siebert U, Das K (2015) Effects of methylmercury on harbour seal peripheral blood leucocytes in vitro studied by electron microscopy. Arch Environ Contam Toxicol. doi:10.1007/s00244-015-0207-y
Dupont A, Siebert U, Covaci A, Weijs L, Eppe G, Debier C, De Pauw-Gillet MC, Das K (2013) Relationships between in vitro lymphoproliferative responses and levels of contaminants in blood of free-ranging adult harbour seals (Phoca vitulina) from the North Sea. Aquat Toxicol 142:210-220

Foltz KM, Baird RW, Ylitalo GM, Jensen BA (2014) Cytochrome P4501A1 expression in blubber biopsies of endangered false killer whales (Pseudorca crassidens) and nine other odontocete species from Hawai'i. Ecotoxicol 23:1607-1618

Fossi MC, Marsili L, Neri G, Casini S, Bearzi G, Politi E, Zanardelli M, Panigada S (2000) Skin biopsy of Mediterranean cetaceans for the investigation of interspecies susceptibility to xenobiotic contaminants. Mar Environ Res 50:517-521

Fossi MC, Marsili L, Casini S, Bucalossi D (2006) Development of new tools to investigate toxicological hazard due to endocrine disruptor organochlorines and emerging contaminants in Mediterranean cetaceans. Mar Environ Res 62:200-204

Fossi MC, Casini S, Bucalossi D, Marsili L (2008) First detection of CYP1A1 and CYP2B induction in Mediterranean cetacean skin biopsies and cultured fibroblasts by Western blot analysis. Mar Environ Res 66:3-6

Freeman HC, Sangalang GB (1977) A study of the effects of methyl mercury, cadmium, arsenic, selenium, and a PCB (aroclor 1254) on adrenal and testicular steroidogeneses in vitro, by the gray seal Halichoerus grypus. Arch Environ Contam Toxicol 5:369-383

Frouin H, Lebeuf M, Saint-Louis R, Hammill M, Pelletier É, Fournier M (2008) Toxic effects of tributyltin and its metabolites on harbour seal (Phoca vitulina) immune cells in vitro. Aquat Toxicol 90:243-251

Gauthier JM, Dubeau H, Rassart E (1999) Induction of micronuclei in vitro by organochlorine compounds in beluga whale skin fibroblasts. Mutat Res 439:87-95

Glad T, Bernhardsen P, Nielsen KM, Brusetti L, Andersen M, Aars J, Sundset MA (2010) Bacterial diversity in faeces from polar bears (Ursus maritimus) in Arctic Svalbard. BMC Microbiol 10:1-10. doi:10.1186/1471-2180-10-10

Goldstein T, Zabka TS, DeLong RL, Wheeler EA, Ylitalo G, Bargu S, Silver M, Leighfield T, Van Dolah F, Langlois G, Sidor I, Dunn JL, Gulland FMD (2009) The role of domoic acid in abortion and premature parturition of California sea lions (Zalophus californianus) on San Miguel Island, California. J Wildl Dis 45:91-108

Gray JS (2002) Biomagnification in marine systems: the perspective of an ecologist. Mar Pollut Bull 45:46-52

Habran S, Pomeroy PP, Debier C, Das K (2013) Changes in trace elements during lactation in a marine top predator, the grey seal. Aquat Toxicol 126:455-466

Hall AJ, Kalantzi OI, Thomas GO (2003) Polybrominated diphenyl ethers (PBDEs) in grey seals during their first year of life-are they thyroid hormone endocrine disruptors? Environ Pollut 126:29-37

Hansen AMK, Bryan CE, West K, Jensen BA (2015) Trace element concentrations in liver of 16 species of cetaceans stranded on Pacific islands from 1997 through 2013. Arch Environ Contam Toxicol. doi:10.1007/s00244-015-0204-1

Hickie BE, Mackay D, de Koning J (1999) Lifetime pharmacokinetic model for hydrophobic contaminants in marine mammals. Environ Toxicol Chem 18:2622-2633

Hickie BE, Kingsley MCS, Hodson PV, Muir DCG, Béland P, Mackay D (2000) A modeling-based perspective on the past, present, and future polychlorinated biphenyl contamination of the St. Lawrence beluga whale (Delphinapterus leucas) population. Can J Fish Aquat Sci 57:101-112

Houde M, Hoekstra PF, Solomon KR, Muir DCG (2005) Organohalogen contaminants in delphinoid cetaceans. Rev Environ Contam Toxicol 184:1-57 
Hunt KE, Moore MJ, Rolland RM, Kellar NM, Hall AJ, Kershaw J, Raverty SA, Davis CE, Yeates LC, Fauquier DA, Rowles TK, Kraus SD (2013) Overcoming the challenges of studying conservation physiology in large whales: a review of available methods. Conserv Biol 1:1-24. doi:10.1093/conphys/cot006

Jaspers VL, Dietz R, Sonne C, Letcher RJ, Eens M, Neels H, Born EW, Covaci A (2010) A screening of persistent organohalogenated contaminants in hair of East Greenland polar bears. Sci Total Environ 408:5613-5618

Jin L, Gaus C, Escher BI (2015) Bioanalytical approaches to understanding toxicological implications of mixtures of persistent organic pollutants in marine wildlife. In: Zeng EY (ed) Comprehensive analytical chemistry, vol 67. Elsevier, Amsterdam, pp 57-84

Jin L, Gaus C, van Mourik L, Escher BI (2013) Applicability of passive sampling to bioanalytical screening of bioaccumulative chemicals in marine wildlife. Environ Sci Technol 47:7982-7988

Kakuschke A, Griesel S (2015) Essential and toxic elements in blood samples of harbor seals (Phoca vitulina) from the Islands Helgoland (North Sea) and Anholt (Baltic Sea): a comparison study with urbanized areas. Arch Environ Contam Toxicol. doi:10.1007/s00244-015-0205-0

Kakuschke A, Valentine-Thon E, Griesel S, Fonfara S, Siebert U, Prange A (2011) Are metal-induced hypersensitivities in harbor seals associated with liver function? Mar Pollut Bull 62: 1891-1894

Kim GB, Nakata H, Tanabe S (1998) In vitro inhibition of hepatic cytochrome $\mathrm{P} 450$ and enzyme activity by butyltin compounds in marine mammals. Environ Pollut 99:255-261

Lavery TJ, Roudnew B, Gill P, Seymour J, Seuront L, Johnson G, Mitchell JG, Smetacek V (2010) Iron defecation by sperm whales stimulates carbon export in the Southern Ocean. Proc R Soc B 277:3527-3531

Law RJ, Bersuder P, Barry J, Deaville R, Reid RJ, Jepson PD (2010) Chlorobiphenyls in the blubber of harbour porpoises (Phocoena phocoena) from the UK: levels and trends 1991-2005. Mar Pollut Bull 60:470-473

Lehnert K, Ronnenberg K, Weijs L, Covaci A, Das K, Hellwig V, Siebert U (2015) Xenobiotic and immune-relevant molecular biomarkers in harbor seals as proxies for pollutant burden and effects. Arch Environ Contam Toxicol. doi:10.1007/s00244-0150202-3

Levin M, Morsey B, Mori C, de Guise S (2004) Specific non-coplanar PCB-mediated modulation of bottlenose dolphin and beluga whale phagocytosis upon in vitro exposure. J Toxicol Environ Health A 67:1517-1535

Levin M, Leibrecht H, Mori C, Jessup D, De Guise S (2007) Immunomodulatory effects of organochlorine mixtures upon in vitro exposure of peripheral blood leukocytes differ between free-ranging and captive southern sea otters (Enhydra lutris). Vet Immunol Immunopathol 119:269-277

Lundin J, Dills R, Ylitalo G, Hanson MB, Emmons C, Schorr G, Ahmad J, Hempelmann J, Parsons K, Wasser S (2015) Persistent organic pollutant determination in killer whale scat samples: optimization of a gas chromatography/mass spectrometry method and application to field samples. Arch Environ Contam Toxicol. doi:10.1007/s00244-015-0218-8

Marcus J, Don Bowen W, Eddington JD (1998) Effects of meal size on otolith recovery from fecal samples of gray and harbor seal pups. Mar Mamm Sci 14:789-802

Marsili L, Fossi MC, Neri G, Casini S, Gardi C, Palmeri S, Tarquini E, Panigada S (2000) Skin biopsies for cell cultures from Mediterranean free-ranging cetaceans. Mar Environ Res 50: 523-526

Marsili L, Casini S, Bucalossi D, Porcelloni S, Maltese S, Fossi MC (2008) Use of immunofluorescence technique in cultured fibroblasts from Mediterranean cetaceans as new "in vitro" tool to investigate effects of environmental contaminants. Mar Environ Res 66:151-153

McHuron E, Peterson S, Ackerman J, Melin S, Harris J, Costa D (2015) Effects of age, colony, and sex on mercury concentrations in California sea lions. Arch Environ Contam Toxicol. doi:10. 1007/s00244-015-0201-4

Mori C, Morsey B, Levin M, Nambiar PR, De Guise S (2006) Immunomodulatory effects of in vitro exposure to organochlorines on $\mathrm{T}$-cell proliferation in marine mammals and mice. J Toxicol Environ Health A 69:283-302

Nakata H, Sakakibara A, Kanoh M, Kudo S, Watanabe H, Nagai N, Miyazaki N, Asano Y, Tanabe S (2002) Evaluation of mitogeninduced responses in marine mammal and human lymphocytes by in vitro exposure of butyltins and non-ortho coplanar PCBs. Environ Pollut 120:245-253

Newman JW, Vedder JM, Jarman WM, Chang RR (1994) A method for the determination of environmental contaminants in living marine mammals using microscale samples of blubber and blood. Chemosphere 29:671-681

Noel M, Jefferies S, Lambourn D, Telmer K, Macdonald R, Ross PS (2015) Mercury accumulation in harbour seals from the northeastern Pacific Ocean: the role of transplacental transfer, lactation, age and location. Arch Environ Contam Toxicol. doi:10.1007/s00244-015-0193-0

Pavlova V, Grimm V, Dietz R, Sonne C, Vorkamp K, Riget F, Letcher R, Gustavson K, Desforges JP, Nabe-Nielsen J (2015) Modeling population-level consequences of polychlorinated biphenyl exposure in East Greenland polar bears. Arch Environ Contam Toxicol. doi:10.1007/s00244-015-0203-2

Pavlova V, Nabe-Nielsen J, Dietz R, Svenning JC, Vorkamp K, Riget FF, Sonne C, Letcher RJ, Grimm V (2014) Field metabolic rate and PCB adipose tissue deposition efficiency in East Greenland polar bears derived from contaminant monitoring data. PLoS One 9(8):e104037. doi:10.1371/journal.pone.0104037

Peterson SH, McHuron EA, Kennedy SN, Ackerman JT, Rea LD, Castellini JM, O'Hara TM, Costa DP (2015) Evaluating hair as a predictor of blood mercury: the influence of ontogenetic phase and life history in pinnipeds. Arch Environ Contam Toxicol. doi:10.1007/s00244-015-0174-3

Ramprashad F, Ronald K (1977) A surface preparation study on the effect of methyl mercury on the sensory hair cell population in the cochlea of the harp seal (Pagophilus groenlandicus Erxleben, 1977). Can J Zool 55:223-230

Reijnders PJH (1986) Reproductive failure in common seals feeding on fish from polluted coastal waters. Nature 324:456-457

Reiner J, Becker P, Gribble M, Lynch J, Moors A, Ness J, Peterson D, Pugh R, Ragland T, Rimmer C, Rhoderick J, Schantz M, Trevillian J, Kucklick J (2015) Organohalogen contaminants and vitamins in northern fur seals (Callorhinus ursinus) collected during subsistence hunts in Alaska. Arch Environ Contam Toxicol. doi:10.1007/s00244-015-0179-y

Roman J, McCarthy JJ (2010) The whale pump: marine mammals enhance primary productivity in a coastal basin. PLoS One 5(10):e13255. doi:10.1371/journal.pone.0013255

Ross PS (2000) Marine mammals as sentinels in ecological risk assessment. Hum Ecol Risk Assess 6:29-46

Ross P, De Swart R, Addison R, Van Loveren H, Vos J, Osterhaus A (1996a) Contaminant-induced immunotoxicity in harbour seas: wildlife at risk? Toxicology 112:157-169

Ross PS, De Swart RL, Timmerman HH, Reijnders PJH, Vos JG, Van Loveren H, Osterhaus ADME (1996b) Suppression of natural killer cell activity in harbour seals (Phoca vitulina) fed Baltic Sea herring. Aquat Toxicol 34:71-84

Simon E, van Velzen M, Brandsma SH, Lie E, Løken K, de Boer J, Bytingsvik J, Jenssen BM, Aars J, Hamers T, Lamoree MH 
(2013) Effect-directed analysis to explore the polar bear exposome: identification of thyroid hormone disrupting compounds in plasma. Environ Sci Technol 47:8902-8912

Sonne C, Gustavson K, Riget FF, Dietz R, Birkved M, Letcher RJ, Bossi R, Vorkamp K, Born EW, Petersen G (2009) Reproductive performance in East Greenland polar bears (Ursus maritimus) may be affected by organohalogen contaminants as shown by physiologically-based pharmacokinetic (PBPK) modelling. Chemosphere 77:1558-1568

Spinsanti G, Panti C, Bucalossi D, Marsili L, Casini S, Frati F, Fossi MC (2008) Selection of reliable reference genes for qRT-PCR studies on cetacean fibroblast cultures exposed to OCs, PBDEs, and 17ß-estradiol. Aquat Toxicol 87:178-186

Tanabe S, Iwata H, Tatsukawa R (1994) Global contamination by persistent organochlorines and their ecotoxicological impact on marine mammals. Sci Total Environ 154:163-177

Thomas GO, Moss SEW, Asplund L, Hall AJ (2005) Absorption of decabromodiphenyl ether and other organohalogen chemicals by grey seals (Halichoerus grypus). Environ Pollut 133:581-586

Tilbury KL, Stein JE, Krone CA, Brownell RL, Blokhin SA, Bolton JL, Ernest DW (2002) Chemical contaminants in juvenile gray whales (Eschrichtius robustus) from a subsistence harvest in Arctic feeding grounds. Chemosphere 47:555-564

Tillander M, Miettinen JK, Koivisto I (1972) Excretion rate of methyl mercury in the seal (Pusa hispida). In: Ruivo M (ed) Marine pollution and sea life. FAO Fishing News, London, pp 303-306

Van de Ven WSM, Koeman JH, Svenson A (1979) Mercury and selenium in wild and experimental seals. Chemosphere 8:539-555
Weijs L, Das K, Siebert U, van Elk N, Jauniaux T, Neels H, Blust R, Covaci A (2009) Concentrations of chlorinated and brominated contaminants and their metabolites in serum of harbour seals and harbour porpoises. Environ Int 35:842-850

Weijs L, Hickie BE, Blust R, Covaci A (2014) Overview of the current state-of-the-art for bioaccumulation models in marine mammals. Toxics 2:226-246

Wenzel C, Adelung D, Kruse H, Wassermann O (1993) Trace metal accumulation in hair and skin of the harbour seal, Phoca vitulina. Mar Pollut Bull 26:152-155

White RD, Shea D, Schlezinger JJ, Hahn ME, Stegeman JJ (2000) In vitro metabolism of polychlorinated biphenyl congeners by beluga whale (Delphinapterus leucas) and pilot whale (Globicephala melas) and relationship to cytochrome $\mathrm{P} 450$ expression. Comp Biochem Physiol C 126:267-284

Wilson JY, Wells R, Aguilar A, Borrell A, Tornero V, Reijnders P, Moore Michael, Stegeman JJ (2007) Correlates of cytochrome P450 1A1 expression in bottlenose dolphin (Tursiops truncatus) integument biopsies. Toxicol Sci 97:111-119

Yordy JE, Mollenhauer MA, Wilson RM, Wells RS, Hohn A, Sweeney J, Schwacke TK, Kucklick JR, Peden-Adams MM (2010) Complex contaminant exposure in cetaceans: a comparative E-screen analysis of bottlenose dolphin blubber and mixtures of four persistent organic pollutants. Environ Toxicol Chem 29:2143-2153 